\title{
Enhancement of the Impaired Autologous Mixed Leukocyte Reaction in Patients with Systemic Lupus Erythematosus
}

\author{
Mary Kuntz Crow \\ Department of Medicine, The Hospital for Special Surgery, and The New York Hospital-Cornell University \\ Medical College, and The Rockefeller University, New York 10021
}

\begin{abstract}
The cellular basis of the impaired autologous mixed leukocyte reaction (AMLR) in patients with systemic lupus erythematosus (SLE) was investigated. Non-T cells from normal subjects and from SLE patients were fractionated into low and high density subpopulations. SLE patients were found to have an increased proportion of low density to high density non-T cells when compared to normal subjects. Although normal low-density non-T cells were highly enriched in AMLR stimulatory capacity, SLE low-density non-T cells induced minimal proliferation by autologous $T$ cells. Brief incubation of SLE non-T cells with phorbol myristate acetate or formalin-treated Staphylococcus aureus resulted in marked augmentation of the capacity of those non-T cells to stimulate an AMLR, although the magnitude of the activated non-T cell-induced AMLR did not achieve that observed in normal subjects. No significant alterations in the expression of Ia molecules on the surface of the non-T cells were detected after in vitro activation. These experiments support the hypothesis that the impaired capacity of SLE T lymphocytes to proliferate in response to autologous non-T cells may in part represent a failure of SLE non-T cells to present an appropriate stimulus for the generation of a $T$ cell response.
\end{abstract}

\section{Introduction}

Systemic lupus erythematosus (SLE) ${ }^{1}$ is a disease characterized by the production of autoantibodies to various nuclear, cytoplasmic, and cell surface antigens (1). It is manifest clinically by widespread tissue damage, at least in part attributable to those autoantibodies $(1,2)$. Although antibodies of similar specificities may be made under certain circumstances in normal individuals (3-5), control mechanisms presumably exist that limit the production of immunoglobulins with the potential for damage of autologous tissue. In patients with SLE, surch regulatory controls have failed.

This work was presented in part at a poster session at the June 1984 meeting of the American Rheumatism Association.

Received for publication 5 October 1984 and in revised form 19 March 1985.

1. Abbreviations used in this paper: AMLR, autologous mixed leukocyte reaction; CH50, total hemolytic complement; FACS, fluorescenceactivated cell sorter, FSA, formalin-treated Staphylococcus aureus organism; IL-1 or IL-2, interleukin 1 or 2; PMA, phorbol myristate acetate; SLE, systemic lupus erythematosus; SRBC, sheep erythrocyte.

J. Clin. Invest.

(c) The American Society for Clinical Investigation, Inc. 0021-9738/85/08/0807/09 $\$ 1.00$

Volume 76, August 1985, 807-815
We and others have previously described a marked deficiency in autologous mixed leukocyte reactivity (AMLR) in patients with SLE (6-10). The AMLR is an in vitro system in which $\mathrm{T}$ lymphocytes proliferate in response to irradiated autologous non-T cells $(11,12)$. It has been shown to generate suppressor activity $(13,14)$. Thus, one possible consequence of an impaired AMLR in patients with SLE might be the defective generation of $T$ suppressor cells and the factors responsible for inhibiting autoimmune reactivity.

The cellular basis of the impaired AMLR in patients with SLE has been studied by ourselves and others. Our studies involved MLR-identical twins discordant for SLE, and provided data in support of a defect in the capacity of non- $T$ cells to stimulate autologous $T$ cell proliferation (8). Data from other laboratories have confirmed a non-T cell defect but have also documented impaired interleukin 1 (IL-1) and interleukin 2 (IL-2) production and depressed $\mathrm{T}$ lymphocyte responsiveness in the AMLR of SLE patients $(9,15)$.

The present studies demonstrate that in contrast to untreated non-T cells from patients with SLE, which have little capacity to stimulate autologous $T$ cells, in vitro-activated non- $T$ cells stimulate vigorous autologous $T$ cell proliferation. These data suggest that the impaired capacity of SLE T cells to proliferate in response to autologous non-T cells may result, in part, from a faiture of the non- $T$ cells to deliver the appropriate signal for the generation of an autologous $\mathrm{T}$ cell response.

\section{Methods}

Subjects. Nine control subjects were in good health and derived from laboratory personnel or volunteer blood donors to the New York Blood Center. 10 patients were studied, eight female and two male, who ranged in age from 21 to $58 \mathrm{yr}$. All cases had been followed in the clinic of The Rockefeller University Hospital by staff physicians and met the revised American Rheumatism Association criteria for the diagnosis of SLE (16). Disease activity was assessed based on the presence of hematologic abnormalities (hemolytic anemia or platelet count $<60,000$ ), fever, rash, arthritis, nephritis, serositis, or central nervous system involvement. Patients with none of these abnormalities at the time of study were termed inactive (0), those with one or two of these abnormalities were termed mildly active $(+)$, and those with three or more of these abnormalities were termed active $(++)$. The dose of immunosuppressive drug with which the patient was being treated at the time of study was recorded. Four patients were receiving no prednisone, two patients were receiving $10 \mathrm{mg}$ of prednisone daily, and three patients were receiving $>20 \mathrm{mg}$ of prednisone daily. One patient was on a regimen of Delatestryl, $200 \mathrm{mg}$ intramuscularly, every 2 wk.

Serum complement. Total hemolytic complement (CH50) determinations on the patients' sera were performed in the clinical laboratory of The Rockefeller University Hospital using the sheep erythrocyte (SRBC) hemolysis assay (17). Results are expressed as total hemolytic units, with the normal range being 150-250 U. 
Cell preparations. Peripheral blood mononuclear cells were obtained by Ficoll-Hypaque density gradient centrifugation and $T$ and non- $T$ cells were separated by rosetting with neuraminidase-treated SRBC as previously described (18).

In some experiments, non-T cells were incubated on plastic flasks (no. 3024, Falcon Labware, Oxnard, CA) at $2 \times 10^{6}$ cells $/ \mathrm{ml}$ in RPMI 1640 (M. A. Bioproducts, Walkersville, MD) containing $10 \%$ fetal calf serum (Armour Pharmaceutical Company, Kankakee, IL) at $37^{\circ} \mathrm{C}$ for $16 \mathrm{~h}$. Nonadherent cells, depleted of some macrophages, were removed and fractionated into high and low density subpopulations as follows: $10-20 \times 10^{6}$ cells were suspended in $2 \mathrm{ml}$ of $100 \%$ Percoll (Pharmacia Fine Chemicals, Piscataway, NJ) in a 15-ml tube (Falcon Labware, no. 2057). $2 \mathrm{ml}$ of 50\% and $2 \mathrm{ml}$ of $30 \%$ Percoll were then carefully layered onto the $100 \%$ Percoll and the tube was centrifuged at 2,300 rpm for $12 \mathrm{~min}$. High density cells were obtained from the $50 / 100 \%$ interface and low density cells from the $30 / 50 \%$ interface.

Activation of non-T cells. Non-T cell preparations were adjusted to $3-4 \times 10^{6}$ cells/ml in RPMI 1640 containing $10 \%$ fetal calf serum and incubated in $5 \mathrm{ml}$ plastic tubes (Falcon Labware, no. 2054) with an equal volume of medium or medium containing $4 \beta$-phorbol $12 \beta$ myristate $13 \alpha$-acetate (PMA, Sigma Chemical Co., St. Louis, MO) or formalin-treated Staphylococcus aureus organisms (FSA, Pansorbin, Calbiochem-Behring Corp., La Jolla, CA). Optimal mitogen doses were determined in preliminary experiments and were $500 \mathrm{ng} / \mathrm{ml}$ PMA and $0.05 \%$ FSA.

Non-T cells were cultured at $37^{\circ} \mathrm{C}$ for $16 \mathrm{~h}$. At the end of the culture period all cells were washed five times with phosphate-buffered saline, the cells counted and resuspended in complete culture medium, which was composed of RPMI 1640 with $10 \%$ human AB serum, 1\% penicillin, and streptomycin (Gibco Laboratories, Grand Island, NY) and $1 \%$ glutamine (Gibco Laboratories).

AMLR cultures. Triplicate cultures were established in roundbottom microtiter plates (Linbro, Flow Laboratories, Inc., McLean, VA) in a volume of $0.2 \mathrm{ml}$ containing $1 \times 10^{5} \mathrm{~T}$ lymphocytes and 1 $\times 10^{5}$ stimulator cells which had been irradiated with 3,000 rads from a cesium source. In some experiments, stimulator cells were incubated with $100 \mu \mathrm{g} / \mathrm{ml}$ mitomycin C (Sigma Chemical Co.) at $37^{\circ} \mathrm{C}$ for 30 min and then washed three times before culture. $T$ cells were also incubated with varying doses of PMA or FSA. Control cultures contained $T$ cells and complete culture medium. AMLR cultures were incubated for $61 / 2 \mathrm{~d}$ in a $5 \% \mathrm{CO}_{2}$ incubator at $37^{\circ} \mathrm{C}$. To assess $\mathrm{T}$ cell proliferation, $2 \mu$ l of $\left[{ }^{3} \mathrm{H}\right]$ thymidine (sp act $1.9 \mathrm{Ci} / \mathrm{mmol}$, Schwarz) Mann Div., Becton, Dickinson \& Co., Orangeburg, NY) were added to each culture well during the last $16 \mathrm{~h}$ of culture. The cultures were transferred to filter paper using an automated cell harvester and $\left[{ }^{3} \mathrm{H}\right]$ thymidine incorporation was measured in a beta counter. Results are reported as the mean counts per minute of triplicate cultures.

Cell surface staining. Characterization of the cell types comprising the non-T cell populations and the low- and high-density non-T subpopulations, as well as determination of the percentage of resting and activated non- $T$ cells that carried surface Ia molecules, were achieved by the staining of those cells with monoclonal or heteroantibodies. Antibodies used included OKT3 (Ortho Pharmaceutical Corporation, Raritan, NJ), MO2 (Coulter Immunology, Hialeah, FL), VG2 (anti-Ia framework determinant, prepared by Dr. Shu Man Fu, Oklahoma Medical Research Foundation), and SG171 (anti-DR monoclonal antibody kindly provided by Dr. J. Silver, The Hospital for Joint Diseases, New York). Heteroantibodies included fluoresceinconjugated $\mathrm{F}\left(\mathrm{ab}^{\prime}\right)_{2}$ fragments of goat anti-human immunoglobulin (Ig) antibody and fluorescein-conjugated $F\left(a b^{\prime}\right)_{2}$ fragments of goat antimouse Ig antibody (both from Tago, Inc., Burlingame, CA). The percentage of cells that stained positively was quantitated using fluorescence microscopy (for OKT3) or a Cytofluorograf 30-H (fluorescenceactivated cell sorter [FACS] Ortho Instruments, Westwood, MA). The intensity of fluorescence was assessed by observation of the histogram pattern on FACS.

\section{Results}

Fractionation of non-T cells into low and high density subpopulations. It has been previously shown in normal subjects that cells that stimulate autologous $T$ cell proliferation are found in the low density fraction of non-T cells (19-22). This fraction contains some macrophages, dendritic cells, and presumably in vivo-activated B lymphocytes. The high density fraction, containing small resting B cells and some null cells, stimulates autologous $\mathrm{T}$ cells poorly. It was possible that the low density cells of SLE patients were either fewer in number or impaired in their stimulatory capacity when compared to low density cells from normal donors. We fractionated non-T cells, which had been depleted of some macrophages by 16-h adherence, from four normal subjects and from four SLE patients into low and high density subpopulations, quantitated the yield of low- and high-density non-T cells, and studied the AMLR stimulatory capacities of those cell preparations (Table I). When the cell yields of low- and high-density non-T cells from the normal subjects and SLE patients were compared, approximately two-thirds of the normal non-T cells fell into the high density fraction, whereas approximately two-thirds of the non$T$ cells were in the low density fraction in the SLE patients. Whereas the low-density non-T fraction from the normal subjects was enriched in AMLR stimulatory capacity when compared with unfractionated non-T cells, the low-density

Table I. Fractionation of AMLR Stimulator Cells into Low and High Density Subpopulations

\begin{tabular}{|c|c|c|c|c|c|c|c|c|c|c|}
\hline \multirow[b]{3}{*}{ Stimulator } & \multirow[b]{3}{*}{ Responder } & \multicolumn{9}{|c|}{ Difference in $[3 \mathrm{H}]$ thymidine incorporated* } \\
\hline & & \multicolumn{5}{|c|}{ Normal subjects } & \multicolumn{4}{|c|}{ SLE patients } \\
\hline & & 1 & 2 & 3 & 4ał & $4 b \ddagger$ & 1 & 2 & 3 & 4 \\
\hline & & $\Delta c p m$ & $\Delta c p m$ & $\Delta c p m$ & $\Delta c p m$ & $\Delta c p m$ & $\Delta c p m$ & $\Delta c p m$ & $\Delta c p m$ & $\Delta c p m$ \\
\hline Non-T & $\mathrm{T}$ & 6,535 & 6,027 & 27,687 & 10,191 & 11,377 & 20 & 286 & 889 & ND\$ \\
\hline Non-T low density & $T$ & 22,157 & 10,814 & 30,087 & ND & ND & -330 & 735 & 412 & 226 \\
\hline Non-T high density & $\mathrm{T}$ & 1,283 & 1,268 & 1,008 & 3,338 & 3,312 & -417 & -6 & -205 & -74 \\
\hline
\end{tabular}

\footnotetext{
* 16-h nonadherent SRBC rosette-negative cells were fractionated into low and high density subpopulations, irradiated, and used as stimulator cells in 61/2-d AMLRs. The counts per minute of $T$ cells incubated with medium is subtracted from the counts per minute of $T$ cells incubated with the various autologous non-T fractions to give $\Delta \mathrm{cpm}$. The percentage of the low plus high density cells found in the low density fraction was 23.7 \pm SE 13.7 for the normal subjects and $68.2 \pm$ SE 10 for the SLE patients. ₹ Unfractionated and high density non-T cells from normal subject 4 were treated with 3,000 rads $(4 a)$ or mitomycin $C(4 b)$ prior to culture. $\$$ Not done.
} 
non-T cell fraction from the SLE patients elicited minimal, if any, autologous $T$ cell proliferation. As expected, the high density subpopulations from both normal subjects and SLE patients had little AMLR stimulatory capacity. The poor stimulation induced by the high density subpopulation was not attributable to the greater radiation sensitivity of those cells, as has been reported in a murine system (23). Previous experiments showed that mitomycin $C$ treatment of normal high density cells resulted in AMLR stimulation comparable to that obtained with irradiated high density cells (21). That result was verified with normal subject 4 (Table I). The composition of the unfractionated, low-density and high-density non-T cell subpopulations was compared in the normal subjects and SLE patients by means of cell surface staining with monoclonal or heteroantibodies and analysis on FACS (Table II). The low-density non-T cells obtained from the SLE patients demonstrated a trend toward increased percentages of cells reacting with an antimonocyte monoclonal antibody (MO2) or with an anti-Ig antibody when compared to the low density cells obtained from normal subjects. Normal lowdensity non-T cells apparently included more cells bearing neither T3, MO2, nor surface Ig than did the SLE low density cells. Thus, although the SLE patients had an adequate, in fact increased, proportion of low-density non-T cells, those cells stimulated autologous $T$ cell proliferation poorly. Whether this impaired stimulatory capacity was attributable to inhibition by a slight increase in macrophages, to a paucity of null or dendritic cells (which lack T3, MO2, and surface Ig) or to other factors could not be determined from these experiments.

Augmentation of $A M L R$ stimulatory capacity by preincubation of non- $T$ cells with $B$ cell activators. Studies from a number of laboratories have demonstrated that the stimulatory capacity in allogeneic or AMLRs of isolated B lymphocytes or non-T cells from normal subjects can be augmented by incubation with $B$ cell mitogens $(21,24-27)$. This effect is most evident with high density B cells (21).

We asked whether the AMLR in patients with SLE could be enhanced if an appropriate stimulus were presented. Non$\mathrm{T}$ cells were incubated for $16 \mathrm{~h}$ with PMA, a tumor promoter that has the capacity to induce $B$ cell differentiation, or with FSA, a relatively $T$-independent $B$ cell mitogen. These cells were then exhaustively washed to remove the activators, irra- diated, and cultured with autologous $T$ cells (Table III). Activated non-T cells from normal subjects stimulated three times as much (PMA) or two times as much (FSA) thymidine incorporation by autologous $T$ cells when compared to the base-line AMLR. It should be noted that several subjects (normal subjects 1 and 3) had an augmented response when using one activator and not the other. In addition, the subjects with the most vigorous baseline AMLRs (subjects 4, 5, and 6) showed minimal augmentation, or a decrease, over their already excellent response after treatment of their non- $T$ cells with the B cell activators. It may be that the non-T cells from these normal subjects had been activated in vivo and that in vitro treatment was less capable of increasing their AMLR stimulatory activity.

The AMLRs in patients with SLE were impaired when non- $T$ cells were used to stimulate $T$ cell proliferation. However, in vitro-activated non-T cells from SLE patients stimulated a vigorous AMLR. The mean thymidine incorporation induced by PMA-activated non-T cells was 29 times greater and that induced by FSA-activated non-T cells was 14 times greater than that stimulated by untreated non-T cells. As was true in normal subjects, there were several patients (subjects 5 and 10) who demonstrated an augmented AMLR after non-T cell activation with one mitogen, but not the other.

Experiments were performed in which varying numbers of untreated or PMA-activated stimulator cells were added to the AMLR cultures (Fig. 1). Although the magnitude of the AMLR induced by PMA-activated non-T cells from three normal subjects was approximately twice that of the non-T PMA-stimulated AMLR observed in the three SLE patients studied, the dose-response pattern was similar in the two subject groups. The autologous $\mathrm{T}$ cell proliferation stimulated by $0.5 \times 10^{5}$ activated or untreated non-T cells from normal subjects or activated non-T cells from the SLE patients was about one-half that stimulated by $1 \times 10^{5}$ non-T cells. When the stimulator dose was diminished to $0.1 \times 10^{5}$ cells, the AMLR induced by activated or untreated non-T cells was not distinguishable from background $T$ cell proliferation in either normal or SLE subjects.

It was possible that carryover of $B$ cell activator into the AMLR cultures accounted for some of the $T$ cell proliferation observed. Table III provides data that shows the $\left[{ }^{3} \mathrm{H}\right]$ thymidine

Table II. Characterization of Non-T Cell Subpopulations*

\begin{tabular}{|c|c|c|c|c|c|c|c|c|}
\hline & \multicolumn{8}{|c|}{ Percentage of cells positive } \\
\hline & \multicolumn{4}{|c|}{ Normal subjects $(n=7)$} & \multicolumn{4}{|c|}{ SLE patients $(n=6)$} \\
\hline & T3 & MO2 & Ig & Ia & T3 & MO2 & Ig & Ia \\
\hline & $\%$ & $\%$ & $\%$ & $\%$ & \% & $\%$ & $\%$ & $\%$ \\
\hline Non-T unfractionated & $<3$ & $37 \pm 4.1$ & $57 \pm 4.7$ & $56 \pm 6.1$ & $<2$ & $39 \pm 7.9$ & $60 \pm 5.0$ & $56 \pm 4.6$ \\
\hline Non-T low density & $<3$ & $24 \pm 4.5$ & $30 \pm 5.5$ & $52 \pm 5.6$ & $<2$ & $39 \pm 4.6$ & $51 \pm 6.9$ & $49 \pm 3.6$ \\
\hline Non-T high density & $<4$ & $9 \pm 4.0$ & $40 \pm 5.7$ & $33 \pm 5.6$ & $<2$ & $40 \pm 11.4$ & $58 \pm 5.7$ & $46 \pm 7.9$ \\
\hline
\end{tabular}

* SRBC rosette-negative mononuclear cells were incubated for $16 \mathrm{~h}$ on plastic, and the nonadherent non-T cells were then fractionated into low and high density subpopulations as described in Methods. Cells were stained with OKT3, MO2, or anti-Ia (VG2) monoclonal antibody followed by fluorescein-labeled $F\left(a b^{\prime}\right)_{2}$ fragments of goat anti-mouse Ig antibody or with fluorescein-labeled $F\left(a b^{\prime}\right)_{2}$ fragments of goat anti-human Ig antibody. Background staining (cells stained with PBS-bovine serum albumin followed by fluorescein-goat anti-mouse Ig) is subtracted from each result. Percentage of cells staining with OKT3 was determined by fluorescence microscopy and percentage of cells bearing MO2, Ig, or Ia/5,000 cells counted was determined by FACS analysis. Results are expressed as mean percentage of positive cells \pm standard error. 
Table III. T Lymphocyte Proliferation Induced by Autologous Activated or Untreated Non-T Cells

\begin{tabular}{|c|c|c|c|c|c|c|c|c|c|}
\hline \multirow[b]{2}{*}{ Subject } & \multirow{2}{*}{$\begin{array}{l}\text { Disease } \\
\text { activity* }\end{array}$} & \multirow[b]{2}{*}{ CH5O } & \multirow[b]{2}{*}{ Prednisone } & \multicolumn{6}{|c|}{ Composition of culture } \\
\hline & & & & $T+$ medium & $\mathbf{T}+\mathbf{N}-\mathbf{T}$ & $T+N-T_{P M A}$ & $T+N-T_{\text {FAA }}$ & $\mathbf{T}+\mathbf{P M A}$ & $T+$ FSA \\
\hline & & & $m g / d$ & \multicolumn{6}{|c|}{ cpm $\left[{ }^{3} \mathrm{H}\right]$ thymidine incorporated $\times 10^{-3} \S$} \\
\hline \multicolumn{10}{|c|}{ Normal } \\
\hline 1 & 0 & ND" & 0 & 0.2 & 2.2 & 33.5 & 4.1 & 0.6 & 0.6 \\
\hline 2 & 0 & ND & 0 & 3.3 & 9.2 & 28.7 & 24.5 & 7.8 & 11.4 \\
\hline 3 & 0 & ND & 0 & 0.5 & 3.0 & 4.5 & 13.3 & 1.4 & 5.4 \\
\hline 4 & 0 & ND & 0 & 0.03 & 32.5 & 27.6 & 22.2 & 0.9 & 3.7 \\
\hline 5 & 0 & ND & 0 & 1.0 & 29.4 & 25.4 & 4.8 & 2.4 & 11.9 \\
\hline 6 & 0 & ND & 0 & 0.7 & 22.4 & 38.9 & ND & ND & ND \\
\hline 7 & 0 & ND & 0 & 0.1 & 7.3 & 69.9 & ND & ND & ND \\
\hline 8 & 0 & ND & 0 & 0.2 & 9.3 & 101.4 & 17.1 & 8.7 & 12.2 \\
\hline \multirow[t]{3}{*}{9} & 0 & ND & 0 & 0.2 & 11.7 & ND & 93.1 & ND & 13.4 \\
\hline & & $\overline{\mathbf{X}} \pm \mathrm{SE}$ & & $0.7 \pm 0.3$ & $14.1 \pm 3.7$ & $41.3 \pm 10.7$ & $25.6 \pm 11.6$ & $3.6 \pm 1.4$ & $8.4 \pm 1.9$ \\
\hline & & & & \multicolumn{6}{|c|}{$\mathrm{cpm}\left[{ }^{3} \mathrm{H}\right]$ thymidine incorporated $\times 10^{-3}$} \\
\hline \multicolumn{10}{|c|}{ SLE patient } \\
\hline 1 & 0 & 228 & $\begin{array}{l}\text { Delatestryl } \\
200 \mathrm{mg} \\
\text { i.m. q } 2 \text { wk }\end{array}$ & 0.2 & 0.5 & 4.9 & 8.9 & 1.8 & 0.4 \\
\hline 2 & 0 & 84 & 0 & 0.2 & 0.4 & 6.5 & 3.2 & 0.9 & 1.0 \\
\hline 3 & + & 179 & 0 & 0.8 & 1.1 & 29.1 & 36.5 & 1.5 & 2.0 \\
\hline 4 & + & 75 & 0 & 0.7 & 2.1 & 7.1 & 18.4 & ND & ND \\
\hline 5 & + & 141 & 10 & 0.3 & 0.4 & 50.6 & 0.8 & 8.0 & 0.3 \\
\hline 6 & + & 140 & 20 & 0.1 & 0.5 & 6.1 & 2.9 & 1.2 & 0.3 \\
\hline 7 & + & 134 & 0 & 0.6 & 0.7 & 25.0 & 17.7 & 1.0 & 1.1 \\
\hline 8 & + & 79 & 30 & 0.5 & 1.0 & 41.0 & 10.8 & 8.0 & 0.4 \\
\hline 9 & ++ & 84 & 25 & 0.5 & 1.4 & ND & 5.8 & ND & 4.8 \\
\hline \multirow[t]{2}{*}{10} & ++ & 116 & 10 & 0.2 & 0.2 & 30.6 & 0.4 & 3.4 & 0.5 \\
\hline & & $\overline{\mathrm{X}} \pm \mathrm{SE}$ & & $0.4 \pm 0.1$ & $0.8 \pm 0.2$ & $22.3 \pm 5.7$ & $10.5 \pm 3.5$ & $3.2 \pm 1.1$ & $1.2 \pm 0.5$ \\
\hline
\end{tabular}

Abbreviations: T, T cells; $\mathrm{N}-\mathrm{T}$, non-T cells; $\mathrm{N}-\mathrm{T}_{\mathrm{PMA}}$, non-T cells activated with PMA; N-T $\mathrm{FSA}_{\mathrm{FA}}$, non-T cells activated with FSA. ${ }^{*}$ Activity of SLE was assessed on the basis of clinical signs and symptoms as described in Methods and noted as 0 (inactive), + (mildly active), or ++ (active). $¥$ CH50 was determined for each patient studied as described in Methods. The normal range for CH50 is 150-250 total hemolytic units. $\$ 1 \times 10^{5} \mathrm{~T}$ lymphocytes were incubated for $61 / 2 \mathrm{~d}$ with complete culture medium, irradiated autologous non-T cells, in vitro-activated non-T cells, or with PMA $500 \mathrm{ng} / \mathrm{ml}$ or FSA $0.05 \%$. $\left[{ }^{3} \mathrm{H}\right.$ ]Thymidine incorporation during the final $16 \mathrm{~h}$ of culture was measured and results are expressed as counts per minute $\times 10^{-3}$. "Not done.

incorporated by $T$ cells incubated for $61 / 2 \mathrm{~d}$ with the same dose of $B$ cell activator with which the non-T cells had been pulsed for $16 \mathrm{~h}$, representing the maximum attributable to carryover

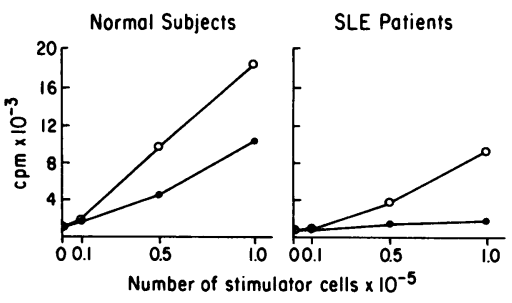

Figure 1. T cell proliferation induced by varying numbers of autologous untreated or PMA-treated non-T cells. T cells from three normal individuals and three SLE patients were cultured in AMLRs with $0.1 \times 10^{5}, 0.5 \times 10^{5}$, or $1.0 \times 10^{5}$ irradiated autologous non-T cells, which had been previously incubated for $16 \mathrm{~h}$ with medium (๑) or with PMA $500 \mathrm{ng} / \mathrm{ml}$ (0). Results are expressed as the mean counts per minute $\times 10^{-3}\left[{ }^{3} \mathrm{H}\right]$ thymidine incorporated by the $\mathrm{T}$ cells from the three subjects in each group during the last $16 \mathrm{~h}$ of culture. of mitogen. In fact, the quantity of PMA and FSA remaining bound to the non-T cells used in the AMLR cultures should be much less after the exhaustive washing of those cells which was performed. Fig. 2 shows the dose response of $\left[{ }^{3} \mathrm{H}\right]$ thymidine incorporation by $\mathrm{T}$ lymphocytes from normal subjects and from SLE patients cultured with a dose of PMA or FSA equivalent to that used to activate the non-T cells, as well as $10 \%$ and $1 \%$ of that dose. Significant proliferation is only seen in normal $\mathrm{T}$ lymphocytes stimulated with $0.05 \% \mathrm{FSA}$, possibly due to leaching of Staph-protein A, a T cell mitogen, from the fixed $S$. aureus organisms. In the AMLR cultures, only a fraction of that quantity of mitogen should be present. Minimal $T$ cell proliferation is induced by either of the mitogens at any dose in the SLE patients. Carryover of mitogen into the AMLR cultures was unlikely, then, to have accounted for the augmentation in $\mathrm{T}$ cell proliferation induced by in vitro-activated non$T$ cells in either the normal subjects or SLE patients.

Augmentation of the AMLR in SLE patients is consistent over time. Three patients with SLE were tested in AMLR cultures on two separate occasions, at least 1 mo apart, to 


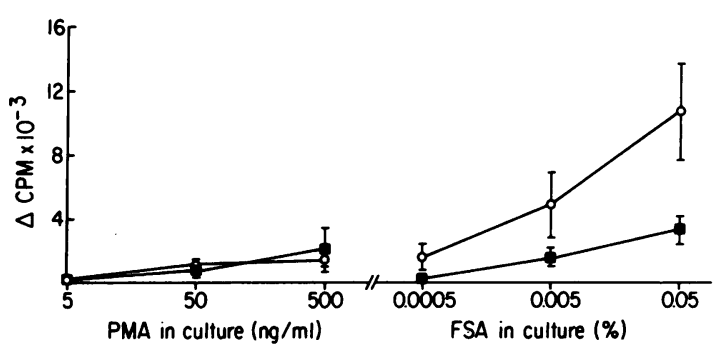

Figure 2. Incorporation of $\left[{ }^{3} \mathrm{H}\right]$ thymidine induced by varying doses of PMA or FSA. T cells from normal subjects (O) or from SLE patients ( $\square$ ) were incubated for $61 / 2 \mathrm{~d}$ with concentrations of PMA or FSA equivalent to those used to activate non-T cells in the previous experiments $(500 \mathrm{ng} / \mathrm{ml}$ for PMA and $0.05 \%$ for FSA) or with $10 \%$ or $1 \%$ of those concentrations. The $T$ cells were then pulsed with $\left[{ }^{3} \mathrm{H}\right]$ thymidine during the last $16 \mathrm{~h}$ of culture and thymidine incorporation was determined. Results are expressed as the mean $\pm \mathrm{SE}$. The counts per minute of $T$ cells cultured alone is subtracted from each result.

determine the consistency of response pattern (Table IV). The base-line AMLR was low in each case. Patient 7 demonstrated augmentation of the AMLR after activation with both PMA and FSA, and the degree of augmentation by FSA was equivalent on both occasions. Patient 5 showed no augmentation of the AMLR in response to FSA on either occasion although augmentation of the AMLR with PMA-pulsed non-T cells was noted. It is interesting that after tapering the prednisone dose from $30 \mathrm{mg}$ daily to $10 \mathrm{mg}$ daily, the PMA-induced AMLR was more dramatically enhanced, perhaps suggesting an inhibitory role of corticosteroids on non- $T$ cell activation or on $T$ cell response to activated non-T cells. Patient 2 had a greater response to PMA-activated than to FSA-activated non-T cells on both occasions. The pattern of response of $T$ cells from SLE patients to autologous in vitro-activated non-T cells is, then, fairly consistent over time.

Percentage of Ia antigen-positive cells in activated and control non-T cell preparations. Cell surface Ia antigen on non$T$ cells is important in stimulating both autologous and allogeneic $T$ lymphocyte proliferation $(18,28)$. The percentage of peripheral blood non- $T$ cells that bear Ia antigens has not been well studied in patients with SLE. It was possible that cells from such patients are deficient in Ia and acquire an increase in this surface molecule after incubation of the non- $T$ cells with activating substances, as has been observed in a murine spleen cell system (29). We determined the percentage of non$T$ cells that stained with an anti-Ia monoclonal antibody after a 16-h incubation with culture medium, PMA or FSA (Table V). Five normal subjects and four SLE patients did not significantly vary in the percentage of their non-T cells which stained with the anti-Ia antibody when assessed on FACS. Neither PMA nor FSA activation resulted in an increase in the percent of Ia positive cells. FSA activation actually resulted in a slight decrease in the number of Ia-bearing non-T cells in the SLE patients. These results were confirmed with a second anti-Ia monoclonal antibody, SG171, which reacts mainly with DR determinants (data not shown). There was no consistent alteration in fluorescence intensity of anti-Ia staining of the activated compared with control non-T cells in either normal subjects or SLE patients (histograms on a representative patient, patient 1, are shown in Fig. 3). We have previously documented the absence of an increase in the intensity of anti-Ia fluorescence after in vitro activation of isolated normal peripheral blood B cells with PMA or FSA (21). It appeared, then, that there was no gross alteration in the number of cells staining with anti-Ia antibody or in the intensity of that staining that might account for the augmentation of the AMLR seen in the SLE patients. These experiments do not rule out alterations in the species of Ia molecules (DR versus $\mathrm{DQ})$ or the degree of sialylation, for example, on the activated, compared with control, non-T cells $(30,31)$.

\section{Discussion}

These studies have examined the cellular basis of the impaired $T$-non-T cell interactions in patients with SLE. We had previously demonstrated a defect in the capacity of the non-T stimulator cell population to induce $\mathrm{T}$ lymphocyte proliferation in these patients $(8)$. Sakane et al. $(7,9)$ have also documented abnormalities of the non-T cell stimulators of the AMLR, but in addition, have detected a defect in $T$ cell proliferative capacity in SLE. More recently, several laboratories have

Table IV. Repeated Testing of Mitogen-activated AMLR in Individual SLE Patients

\begin{tabular}{|c|c|c|c|c|c|c|c|}
\hline \multirow[b]{3}{*}{ Experiment: } & & \multicolumn{6}{|c|}{ SLE patient } \\
\hline & & \multicolumn{2}{|l|}{7} & \multicolumn{2}{|l|}{5} & \multicolumn{2}{|l|}{2} \\
\hline & & 1 & 2 & 1 & 2 & 1 & 2 \\
\hline \multicolumn{2}{|l|}{ Prednisone mg/day: } & None & None & 30 mg & $10 \mathrm{mg}$ & None & None \\
\hline Stimulator & Responder & \multicolumn{6}{|c|}{$\operatorname{cpm}\left[{ }^{3} \mathrm{H}\right]$ thymidine incorporated } \\
\hline Medium & $T$ & 428 & 568 & 430 & 298 & 234 & 1,467 \\
\hline Non- $T$ & $\mathrm{~T}$ & 894 & 687 & 1,315 & 442 & 394 & 877 \\
\hline Non- $T_{P M A}$ & $\mathrm{~T}$ & ND $\ddagger$ & 24,964 & 6,074 & 50,626 & 6,527 & 8,719 \\
\hline Non- $T_{\text {FSA }}$ & $\mathbf{T}$ & 15,828 & 17,695 & 1,570 & 764 & 3,239 & 1,398 \\
\hline PMA & $\mathrm{T}$ & ND & 1,021 & 3,263 & 7,960 & 939 & ND \\
\hline FSA & $\mathbf{T}$ & ND & 1,071 & 862 & 348 & 1,012 & ND \\
\hline
\end{tabular}

\footnotetext{
* Peripheral blood mononuclear cells were obtained from three SLE patients on two occasions at least 1 mo apart. AMLR cultures were established using untreated, PMA-activated, or FSA-activated non-T cells as stimulators. $¥$ Not done.
} 
Table V. Percentage of Activated and Control

Non-T Cells Reactive with an Anti-Ia Antibody

\begin{tabular}{|c|c|c|c|}
\hline \multirow[b]{2}{*}{ Subjects $(n)$} & \multicolumn{3}{|c|}{ Treatment of cells* } \\
\hline & Non- $\mathrm{T}_{\text {mothum }}$ & Non- $T_{\text {PMA }}$ & Non- $T_{\text {PSA }}$ \\
\hline & $\%$ & $\%$ & $\%$ \\
\hline Normals (5) & $60 \pm 3.6$ & $63 \pm 4.7$ & $58 \pm 4.3$ \\
\hline SLE patients (4) & $60 \pm 10.2$ & $63 \pm 8.5$ & $47 \pm 9.9$ \\
\hline
\end{tabular}

Results are expressed as mean percentage \pm standard error.

* SRBC rosette-negative mononuclear cells were incubated for $16 \mathrm{~h}$ with medium, PMA, or FSA (see Methods). The cells were then washed and incubated with mouse anti-human la monoclonal antibody (VG2) and then with $F\left(a^{\prime}\right)_{2}$ fragments of fluorescein-goat antimouse Ig antibody. The percentage of positive cells per 5,000 cells counted and the intensity of fluorescence (see Fig. 3) were evaluated on a cytofluorograph.

documented impaired IL-1 and IL-2 production in SLE patients $(15,32,33)$.

Our experiments examined the capacity of non- $T$ cells fractionated on Percoll gradients to stimulate an AMLR. High-

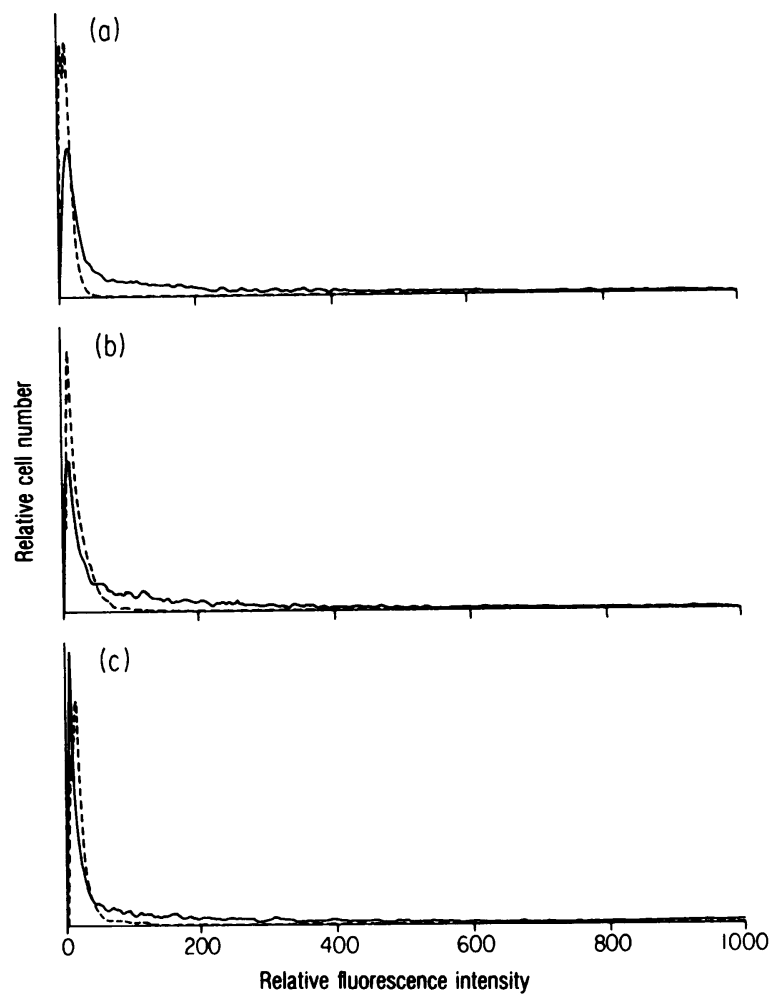

Figure 3. FACS profiles of surface membrane la antigen expression on untreated or PMA- or FSA-activated non-T cells from an SLE patient (patient 1). Non-T cells were incubated for $16 \mathrm{~h}$ with medium, PMA $500 \mathrm{ng} / \mathrm{ml}$, or FSA $0.05 \%$. The cells were then washed and incubated with PBS-bovine serum albumin (-- ) or with monoclonal anti-human Ia, VG2, (-) followed by fluoresceinlabeled goat anti-mouse Ig. 5,000 cells in each sample were analyzed by FACS. The abscissa represents relative fluorescence intensity, and the ordinate represents relative cell number. (a) Non-T cells incubated for $16 \mathrm{~h}$ with medium. (b) Non-T cells incubated for $16 \mathrm{~h}$ with PMA. (c) Non-T cells incubated for $16 \mathrm{~h}$ with FSA. density normal non-T cells are enriched in surface Ig-positive cells, usually of both IgM and IgD isotypes, and probably represent circulating mature "resting" B lymphocytes $(20,34$, 35). The low density fraction of non-T cells is enriched in dendritic cells, activated B cells, and some macrophages (19, 21,35 ). Low density non-T cells contain a lower percentage of surface Ig-positive cells when compared with the high density non-T cells $(20,34)$ and contain a subpopulation of cells which is IgM positive, IgD negative (34). This fraction also contains the lymphocytes that differentiate into antibody secreting cells after pokeweed mitogen stimulation (34). The high-density non-T cell subpopulation from normal subjects is poor in AMLR stimulatory activity, whereas the low-density non-T cell subpopulation is highly enriched in such activity (19-22). When non-T cells from patients with SLE were fractionated into high and low density subpopulations, neither fraction provided significant AMLR stimulatory activity. The proportion of low-density to total non-T cells was relatively increased in the SLE patients, and there was a trend toward increased surface Ig-positive cells and macrophages and an apparent decrease in null cells in the SLE low density fractions when compared with the low-density non-T cells from normal subjects. The finding of increased low-density non-T cells is consistent with data from other laboratories that demonstrate activated B cells among peripheral blood non-T cells in SLE. Spontaneous mitogenesis, spontaneous Ig secretion, and decreased numbers of surface IgD bearing cells have all been reported in studies of the peripheral blood of SLE patients (36-40). Macrophages have been shown to be responsible for the stimulation of proliferation by a defined $\mathrm{T}$ cell subpopulation $(41,42)$, but when large numbers of macrophages are added to AMLR cultures, inhibition of the response has been observed (42). Null cells (mouse erythrocyte rosette-negative non-T cells) have been shown to be enriched in AMLR stimulatory activity (12), as have human peripheral blood dendritic cells $(19,26)$. Dendritic cells are large lymphoid cells with irregular morphology that do not bear $\mathrm{T}$ cell or monocyte markers or surface Ig. The poor AMLR stimulation induced by the low-density non-T cells from the patients could be due, then, to inhibition by a slight excess of macrophages or the lack of an important cell population which does not bear surface markers characteristic of $T$ or $B$ cells or macrophages.

We and others have provided data that demonstrate an augmented capacity for allogeneic or AMLR stimulation in mitogen-activated non-T cells or isolated B cells from normal subjects $(21,24-27)$. It is the high density "resting" B lymphocytes that are most responsible for the augmented AMLR seen after B cell activation (21). We used PMA and FSA, two agents capable of inducing an activated state in B lymphocytes, to study the capacity of SLE non-T cells to generate an enhanced AMLR. Marked augmentation of the uniformly poor base-line AMLR was noted after PMA or FSA activation of the SLE non-T cells, although the mean counts per minute for the SLE patients was still less than the mean counts per minute of the mitogen-augmented AMLR generated by non$T$ cells from normal subjects. It appeared unlikely that carryover of cell-bound mitogen into the AMLR cultures could account for the augmented $\mathrm{T}$ cell proliferation observed, particularly in the SLE patients who demonstrated minimal proliferative response to PMA or FSA alone. Macrophages were present in the non-T cell preparations of both normal subjects and SLE patients, and it is possible that some of the PMA-induced 
effect on the magnitude of the AMLR was attributable to the capacity of PMA to activate macrophages (43). FSA, however, is not known to have an effect on macrophages and is a more specific B lymphocyte activator. The magnitude of the response of $T$ cells to mitogen-activated non- $T$ cells was fairly consistent in three patients who were tested on a second occasion.

These results must be reconciled with information from many laboratories that demonstrates activated $B$ lymphocytes in the peripheral blood of SLE patients (36-40). If in vitroactivated normal $B$ cells and the low density fraction of normal non-T cells, possibly enriched in in vivo-activated B cells, have vigorous AMLR stimulatory activity, why are SLE peripheral blood non-T cells not excellent AMLR stimulators? Further analysis of B cell subpopulations in normal subjects and SLE patients will be necessary in order to explain this paradox, but several possible defects in SLE B cells can be postulated. The B cells may be "activated," but at a point in the B cell differentiation sequence beyond which effective $B$ cell-T cell interactions occur. Many of the B cells contained in the non$T$ cell preparations obtained from SLE patients may be at or near the point of terminal differentiation as demonstrated by their capacity to secrete Ig after only brief in vitro incubation $(37,38)$. As B lymphocytes approach the plasma cell stage, they lose various B cell surface molecules that could be important in facilitating B-T interactions (44). Secondly, SLE peripheral blood B cells may contain an abnormally expanded $B$ cell subpopulation normally present in small numbers, and incapable of stimulating an AMLR. Studies in a murine model of autoimmune disease have demonstrated an expansion of the usually minor B cell subpopulation bearing Ly-1, intense surface IgM, and dull surface IgD (45). The capacity of that B cell subpopulation to stimulate a syngeneic MLR has not been studied. Finally, SLE patients may be deficient in a subpopulation of non-T cells important in AMLR stimulation. "Null" or dendritic cells may represent such a cell type. Whatever the defect in the SLE non-T cells, the fact that those cells can be induced to stimulate vigorous $T$ cell proliferation suggests that SLE patients have a subpopulation of normal B lymphocytes that can be acted upon by mitogens to begin differentiation to the point at which efficient $\mathrm{T}$-non-T cell interactions occur.

Much of the defect in IL-1 or IL-2 production that has been reported in patients with $\operatorname{SLE}(15,32,33)$ has presumably been overcome in our system, as activity of these lymphokines is a prerequisite for $T$ cell proliferation in the AMLR (28). Evidence has also been presented in murine models of SLE that demonstrates increased production of IL-2 by $T$ cells when PMA is added to a concanavalin A-induced proliferation system $(46,47)$. It was felt in these studies that stimulation of increased IL-1 production by the PMA was unlikely to be responsible for the augmented IL-2 production observed. Preliminary experiments in our laboratory also suggest that the more vigorous AMLR seen after mitogen activation of non-T cells from patients with SLE is not attributable to increased IL-1 production. The defects in IL-2 production and response that have been documented by others may not, then, be accounted for entirely by primary abnormalities in the SLE T cell, but rather reflect, in part, the absence of a signal from non-T cells which helps to induce synthesis of lymphokines and possibly their receptors.

The mechanism by which in vitro-activated non-T cells stimulate augmented $\mathrm{T}$ cell proliferation has not been clarified. Ia molecules are essential for the induction of autologous $T$ cell proliferation $(18,28)$. We wondered whether a deficiency in cell surface Ia on SLE non-T cells, which was corrected after in vitro activation, might account for our results. However, no difference was noted between normal and SLE non-T cells in terms of the percentage of cells staining with a monoclonal anti-Ia antibody or in the intensity of staining as assessed by histogram pattern on a cytofluorograph. After in vitro activation with mitogens, there was no consistent increase in these parameters in either normal subjects or in SLE patients. It is possible that further analysis of B cell subpopulations that uses antibodies reactive with various species of class II determinants might reveal specific abnormalities in the SLE cells, which could account for the impaired AMLR and its augmentation after in vitro non-T cell activation. Although the presence of Ia molecules on non-T cells may be necessary for the stimulation of the AMLR, they may not be sufficient for the generation of this in vitro response. Monoclonal antibodies reacting with $B$ cell differentiation molecules have been produced in a number of laboratories $(44,48,49)$. Evaluation of normal and SLE non-T cells in the resting and activated state using such antibodies may help to define a B cell surface molecule, present on normal B cells but not on untreated SLE $B$ cells, which is necessary for stimulation of autologous $T$ cell proliferation.

Many investigators have presented data that suggest that SLE is characterized by primary defects in the B lymphocyte limb of the immune system $(50,51)$. These defects are manifest as polyclonal B cell activation and secretion of autoantibodies of unusual and well-defined specificities. Studies of the $T$ lymphocyte limb of the immune system have also demonstrated deficiencies, and we and others have postulated that impaired or failed regulation of $B$ cells by abnormally functioning $T$ cells may contribute to the overactivity of the B cells of SLE patients $(8,12,51)$. Our data suggest that at least some of the $\mathrm{T}$ cell abnormalities may not be intrinsic to those cells, but rather the result of the absence of a non-T cell signal required for autologous $T$ cell proliferation. When SLE $T$ lymphocytes are presented with a potent stimulator cell, they are capable of vigorous proliferative response. Further studies will be necessary to determine whether helper, suppressor, and cytotoxic activities are generated in the SLE $T$ cells activated in this system.

\section{Acknowledgments}

The author thanks Ms. Julie Behnke for expert technical assistance, Dr. Marc E. Weksler and Dr. Carlo Russo for review of the manuscript, and Ms. Pamela Bolton for assistance in the preparation of the manuscript.

This work was supported in part by grants AI-19080 and AI-10811 from the U. S. Public Health Service. The author is the recipient of a fellowship from the Arthritis Foundation and a Clinical Investigator Award from the National Institutes of Health.

\section{References}

1. Zwaifler, N. J. 1981. Etiology and pathogenesis of systemic lupus erythematosus. In Textbook of Rheumatology. W. N. Kelley, E. D. Harris, S. Ruddy, and C. B. Sledge, editors. W. B. Saunders Co., Philadelphia. 1079-1 105.

2. Koffler, D., V. Agnello, R. Thoburn, and H. G. Kunkel. 1971. Systemic lupus erythematosus: prototype of immune complex nephritis in man. J. Exp. Med. 134:169s-179s. 
3. Hoch, S., P. H. Schur, and J. Schwaber. 1983. Frequency of anti-DNA antibody producing cells from normals and patients with systemic lupus erythematosus. Clin. Immunol. Immunopathol. 27:2837.

4. Blomgren, S. E., J. J. Condemi, and J. H. Vaughan. 1972. Procainamide-induced lupus erythematosus. Clinical and laboratory observations. Am. J. Med. 52:338-348.

5. Cairns, E., J. Block, and D. A. Bell. 1984. Anti-DNA autoantibody-producing hybridomas of normal human lymphoid cell origin. J. Clin. Invest. 74:880-887.

6. Kuntz, M. M., J. B. Innes, and M. E. Weksler. 1976. Impaired immune surveillance in chronic lymphocytic leukemia (CLL) and systemic lupus erythematosus (SLE). Clin. Res. 24:448A. (Abstr.)

7. Sakane, T., A. D. Steinberg, and I. Green. 1978. Failure of autologous mixed lymphocyte reactions between $T$ and non- $T$ cells in patients with systemic lupus erythematosus. Proc. Natl. Acad. Sci. USA. 75:3464-3468.

8. Kuntz, M. M., J. B. Innes, and M. E. Weksler. 1979. The cellular basis of the impaired autologous mixed lymphocyte reaction in patients with systemic lupus erythematosus. J. Clin. Invest. 63:151153.

9. Sakane, T., A. D. Steinberg, F. C. Arnett, J. L. Reinertsen, and I. Green. 1979. Studies of immune functions of patients with systemic lupus erythematosus. III. Characterization of lymphocyte subpopulations responsible for defective autologous mixed lymphocyte reactions. $\mathrm{Ar}$ thritis Rheum. 22:770-776.

10. Smith, J. B., and R. J. DeHoratius. 1982. Deficient autologous mixed lymphocyte reactions correlate with disease activity in systemic lupus erythematosus and rheumatoid arthritis. Clin. Exp. Immunol. 48:155-162.

11. Opelz, G., M. Kiuchi, M. Takasugi, and P. I. Terasaki. 1975. Autologous stimulation of human lymphocyte subpopulations. J. Exp. Med. 142:1327-1333.

12. Kuntz, M. M., J. B. Innes, and M. E. Weksler. 1976. Lymphocyte transformation induced by autologous cells. IV. Human T-lymphocyte proliferation induced by autologous or allogeneic non-T lymphocytes. J. Exp. Med. 143:1042-1054.

13. Innes, J. B., M. M. Kuntz, Y. T. Kim, and M. E. Weksler. 1979. Induction of suppressor activity in the autologous mixed lymphocyte reaction and in cultures with concanavalin A. J. Clin. Invest. 64:1608-1613.

14. Smith, J. B., and R. P. Knowlton. 1979. Activation of suppressor $\mathrm{T}$ cells in human autologous mixed lymphocyte culture. J. Immunol 123:419-422.

15. Alcocer-Varela, J., and D. Alarcon-Segovia. 1982. Decreased production of and response to interleukin-2 by cultured lymphocytes from patients with systemic lupus erythematosus. J. Clin. Invest. 69 : 1388-1392.

16. Tan, E. M., A. S. Cohen, J. F. Fries, A. T. Masi, D. J. McShane, N. F. Rothfield, J. G. Schaller, N. Talal, and R. J. Winchester. 1982. The revised 1982 criteria for the classification of systemic lupus erythematosus. Arthritis Rheum. 25:1271-1277.

17. Mayer, M. M. 1961. Complement and complement fixation. In Experimental Immunochemistry. E. A. Kabat and M. M. Mayer, editors. Charles C Thomas, Springfield, IL. 133-240.

18. Gottlieb, A. B., S. M. Fu, D. T. Y. Yu, C. Y. Wang, J. P Halper, and H. G. Kunkel. 1979. The nature of the stimulatory cell in human allogeneic and autologous MLC reactions: role of isolated IgM-bearing B cells. J. Immunol. 123:1497-1503.

19. Van Voorhis, W. C., L. S. Hair, R. M. Steinman, and G Kaplan. 1982. Human dendritic cells. Enrichment and characterization from peripheral blood. J. Exp. Med. 155:1172-1187.

20. Kabelitz, D., L. Klareskog, and B. Simonsson. 1983. Density separation of chronic lymphocytic leukemia cells: low-density non-T cells are efficient stimulator cells in allogeneic and autologous mixed leukocyte reaction. Clin. Immunol. Immunopathol. 26:287-295.
21. Crow, M. K., and H. G. Kunkel. 1985. Activated B lymphocytes: stimulators of an augmented autologous mixed leukocyte reaction. Cell. Immunol. 90:555-568.

22. Santiago-Schwarz, F., A. C. Bakke, J. G. Woodward, R. L. O'Brien, and D. A. Horwitz. 1985. Further characterization of low density mononuclear cells: FACS-assisted analysis of human MLR stimulators. J. Immunol. 134:779-785.

23. Ashwell, J. D., A. L. DeFranco, W. E. Paul, and R. H. Schwartz. 1984. Antigen presentation by resting B cells: radiosensitivity of the antigen-presentation function and two distinct pathways of $T$ cell activation. J. Exp. Med. 159:881-905.

24. Shin, H. S., C. Y. Wang, and Y. S. Choi. 1981. Activation of autologous reactive helper $\mathrm{T}$ lymphocytes for differentiation of human B lymphocytes. J. Immunol. 126:2485-2489.

25. James, S. P., G. G. Yenokida, A. S. Graeff, and W. Strober. 1982. Activation of suppressor $T$ cells by autologous lymphoblastoid cells: a mechanism for feedback regulation of immunoglobulin synthesis. J. Immunol. 128:1149-1154.

26. Crow, M. K., and H. G. Kunkel. 1982. Human dendritic cells: major stimulators of the autologous and allogeneic mixed leukocyte reactions. Clin. Exp. Immunol. 49:338-346.

27. Palacios, R. 1982. Epstein-Barr virus increases the proliferative response and the generation of suppressor and cytotoxic $T$-cell functions in autologous mixed lymphocyte reaction. Scand. J. Immunol. 15:1724.

28. Palacios, R., and G. Moller. 1981. HLA-DR antigens render resting $T$ cells sensitive to Interleukin-2 and induce production of the growth factor in the autologous mixed lymphocyte reaction. Cell. Immunol. 63:143-153.

29. Monroe, J. G., and J. C. Cambier. 1983. B cell activation. III. B cell plasma membrane depolarization and hyper-Ia antigen expression induced by receptor immunoglobulin cross-linking are coupled. J. Exp. Med. 158:1589-1599.

30. Gonwa, T. A., L. J. Picker, H. V. Raff, S. M. Goyert, J. Silver, and J. D. Stobo. 1983. Antigen-presenting capabilities of human monocytes correlates with their expression of HLA-DS, an Ia determinant distinct from HLA-DR. J. Immunol. 130:706-711.

31. Cowing, C., and J. M. Chapdelaine. 1983. T cells discriminate between Ia antigens expressed on allogeneic accessory cells and B cells: a potential function for carbohydrate side chains on Ia molecules. Proc. Natl. Acad. Sci. USA. 80:6000-6004.

32. Linker-Israeli, M., A. C. Bakke, R. C. Kitridou, S. Gendler, S. Gillis, and D. A. Horwitz. 1983. Defective production of Interleukin 1 and Interleukin 2 in patients with systemic lupus erythematosus (SLE) J. Immunol. 130:2651-2655.

33. Miyasaka, N., T. Nakamura, I. J. Russell, and N. Talal. 1984. Interleukin 2 deficiencies in rheumatoid arthritis and systemic lupus erythematosus. Clin. Immunol. Immunopathol. 31:109-117.

34. Kuritani, T., and M. D. Cooper. 1982. Human B cell differentiation. II. Pokeweed mitogen-responsive B cells belong to a surface immunoglobulin D-negative subpopulation. J. Exp. Med. 155:15611566.

35. Muraguchi, A., J. L. Butler, J. H. Kehrl, and A. S. Fauci. 1983. Differential sensitivity of human B cell subsets to activation signals delivered by anti- $\mu$ antibody and proliferative signals delivered by a monoclonal B cell growth factor. J. Exp. Med. 157:530-546.

36. Glinski, W., M. E. Gershwin, D. R. Budman, and A. D. Steinberg. Study of lymphocyte subpopulations in normal humans and patients with systemic lupus erythematosus by fractionation of peripheral blood lymphocytes on a discontinuous Ficoll gradient. Clin. Exp. Immunol. 26:228-238.

37. Budman, D. R., E. B. Merchant, A. D. Steinberg, B. Doft, M. E. Gershwin, E. Lizzio, and J. P. Reeves. 1977. Increased spontaneous activity of antibody-forming cells in the peripheral blood of patients with active SLE. Arthritis Rheum. 20:829-833.

38. Ginsburg, W. W., F. D. Finkelman, and P. E. Lipsky. 1979. 
Circulating and pokeweed mitogen-induced immunoglobulin-secreting cells in systemic lupus erythematosus. Clin. Exp. Immunol. 35:76-88.

39. Kallenberg, C. G. M., P. C. Limburg, C. Van Slochteren, F. J. Van der Woude, and T. H. The. 1983. B cell activity in systemic lupus erythematosus: depressed in vivo humoral immune response to a primary antigen (haemocyanin) and increased in vitro spontaneous immunoglobulin synthesis. Clin. Exp. Immunol. 53:371-383.

40. Tsokos, G. C., I. T. Magrath, and J. E. Balow. 1983. EpsteinBarr virus induces normal B cell responses but defective suppressor $\mathrm{T}$ cell responses in patients with systemic lupus erythematosus. J. Immunol. 131:1797-1801.

41. Hausman, P. B., H. V. Raff, R. C. Gilbert, L. J. Picker, and J. D. Stobo. 1980. T cells and macrophages involved in the autologous mixed lymphocyte reaction are required for the response to conventional antigen. J. Immunol. 125:1374-1379.

42. Smolen, J. S., T. M. Chused, E. A. Novotny, and A. D. Steinberg. 1982. The human autologous mixed lymphocyte reaction: III. Immune circuits. J. Immunol. 129:1050-1053.

43. Mizel, S. B., D. L. Rosentreich, and J. J. Oppenheim. 1978. Phorbol myristate acetate stimulates LAF production by the macrophage cell line, P388D $\mathrm{D}_{1}$. Cell. Immunol. 40:230-235.

44. Nadler, L. M., P. Stashenko, R. Hardy, A. van Agthoven, C. Terhorst, and S. F. Schlossman. 1981. Characterization of a human B cell-specific antigen (B2) distinct from B1. J. Immunol. 126:19411947.
45. Hayakawa, K., R. R. Hardy, D. R. Parks, and L. A. Herzenberg. 1983. The "Ly-1 B" cell subpopulation in normal, immunodefective, and autoimmune mice. J. Exp. Med. 157:202-218.

46. Santoro, T. J., T. A. Luger, E. S. Raveche, J. S. Smolen, J. J. Oppenheim, and A. D. Steinberg. 1983. In vitro correction of the Interleukin 2 defect of autoimmune mice. Eur. J. Immunol. 13:601604.

47. Davidson, W. F., J. B. Roths, K. L. Holmes, E. Rudikoff, and H. C. Morse III. 1984. Dissociation of severe lupus-like disease from polyclonal B cell activation and IL 2 deficiency in $\mathrm{C} 3 \mathrm{H}-\mathrm{lpr} / \mathrm{lpr}$ mice. J. Immunol. 133:1048-1056.

48. Abramson, C. S., J. H. Kersey, and T. W. LeBien. 1981. A monoclonal antibody (BA-1) reactive with cells of human B lymphocyte lineage. J. Immunol. 126:83-88.

49. Yokochi, T., R. D. Holly, and E. A. Clark. 1982. B lymphoblast antigen (BB-1) expressed on Epstein-Barr virus-activated B cell blasts, B lymphoblastoid cell lines, and Burkitt's lymphomas. J. Immunol. 128:823-827.

50. Tan, P., G. Pang, and J. D. Wilson. 1981. Immunoglobulin production in vitro by peripheral blood lymphocytes in systemic lupas erythematosus: helper $\mathrm{T}$ cell defect and $\mathrm{B}$ cell hyperreactivity. Clin. Exp. Immunol. 44:548-554.

51. Steinberg, A. D., E. S. Raveche, C. A. Laskin, H. R. Smith, T. Santoro, M. L. Miller, and P. H. Plotz. 1984. Systemic lupus erythematosus: insights from animal models. Ann. Intern. Med. 100:714727. 